\title{
Aflatoxin contamination in Tanzania: quantifying the problem in maize and groundnuts from rural households
}

\author{
S.B. Boni ${ }^{1,2}$, F. Beed ${ }^{1,3}$, M.E. Kimanya ${ }^{4}$, E. Koyano ${ }^{1,5}$, O. Mponda ${ }^{6}$, D. Mamiro7 ${ }^{7}$, B. Kaoneka ${ }^{8}$, R. Bandyopadhyay ${ }^{9}$, \\ S. Korie ${ }^{9}$ and G. Mahuku ${ }^{1^{*}}$ \\ ${ }^{1}$ International Institute of Tropical Agriculture (IITA) Eastern Africa Hub, Plot 25, Mwenge Coca-Cola Road, Mikocheni \\ B, P.O. Box 34441, Dar es Salaam, Tanzania; ${ }^{2}$ World Vegetable Center, Eastern and Southern Africa, P.O. Box 10, Duluti, \\ Arusha, Tanzania; ${ }^{3}$ Food and Agriculture Organization of the United Nations (FAO), Viale delle Terme di Caracalla, \\ 00153 Rome, Italy; ${ }^{4}$ The Nelson Mandela African Institute of Science and Technology (NM-AIST), P.O. Box 447, Arusha, \\ Tanzania; ${ }^{5}$ World Vision International, P.O. Box 6070, Arusha, Tanzania; ${ }^{6}$ Department of Research, Ministry of Agriculture, \\ Livestock and Fisheries, P.O. Box 9192 Dar es Salaam, Tanzania; ${ }^{7}$ Sokoine University of Agriculture (SUA), P.O. Box 3000 \\ Chuo Kikuu, Morogoro, Tanzania; ${ }^{8}$ Tropical Pesticides Research Institute (TPRI), Ministry of Agriculture, Livestock and \\ Fisheries, P.O. Box 3024 Arusha, Tanzania; ${ }^{9} I I T A$ Headquarters, PMB 5320, Oyo Road, Ibadan 200001, Oyo State, Nigeria; \\ g.mahuku@cgiar.org
}

Received: 11 September 2020 / Accepted: 7 January 2021

(c) 2021 Wageningen Academic Publishers

\section{OPEN ACCESS @ (1) RESEARCH ARTICLE}

\begin{abstract}
Aflatoxins are toxic and carcinogenic secondary metabolites, produced by Aspergillus flavus and Aspergillus parasiticus, which contaminate food and feed and threaten human and animal health. To assess the prevalence of aflatoxins in Tanzania, 180 groundnut and 200 maize samples were collected from 9 and 10 districts, respectively. Aflatoxin contamination was quantified using high performance liquid chromatography. Aflatoxins were detected in samples collected from all districts and prevalence ranged from 92 to $100 \%$ for groundnuts and 10 to $80 \%$ for maize. The mean aflatoxin level for groundnuts was $6.37 \mu \mathrm{g} / \mathrm{kg}$ and the highly contaminated sample had $40.31 \mu \mathrm{g} / \mathrm{kg}$. For maize, the mean aflatoxin level was $12.47 \mu \mathrm{g} / \mathrm{kg}$ and the highly contaminated sample had $162.40 \mu \mathrm{g} / \mathrm{kg}$. The estimated average probable daily intake (APDI) of aflatoxin $\mathrm{B}_{1}\left(\mathrm{AFB}_{1}\right)$ from groundnuts consumption was $1.88 \mathrm{ng} / \mathrm{kg}$ body weight/day, while for maize, it ranged between $151.98-272.89 \mathrm{ng} / \mathrm{kg}$ body weight/day. The APDI for both groundnut and maize exceeded the provisional maximum tolerable daily intake (PMTDI) of AFB $_{1}$ for adults (1 ng/kg body weight/day), bringing about health concerns for populations in Tanzania. Another alarming finding was that $75 \%$ of the farmers who provided samples for analysis were not aware of aflatoxins or the negative health impacts from consuming contaminated products. Results reported in this paper show that aflatoxin contaminated staple crops are widely distributed in Tanzania and that the risk of human exposure is high due to diet preferences. Awareness campaigns are required to inform and protect farmers and consumers.
\end{abstract}

Keywords: mycotoxin, Aspergillus flavus, aflatoxin exposure

\section{Introduction}

Aflatoxins are poisons produced by fungi belonging to the genus, Aspergillus. The two most important aflatoxin producers, Aspergillus flavus and Aspergillus parasiticus, are ubiquitous in soil (Visconti and Perrone, 2008). Maize and groundnut are most susceptible to contamination with aflatoxins, but other crops such as dried cassava, coffee, chili, tree nuts and legumes can be contaminated (Essono et al., 2007; Manjula et al., 2009). Aflatoxin contamination and prevalence depend on many factors including variability in climatic conditions, type of commodity, agricultural practices and processing and storage conditions (Richard, 2007). According to the United Nations Food and Agriculture Organization (FAO), about $25 \%$ of world food crops are affected by aflatoxins, and the 
highest risks are in tropical countries situated between $43^{\circ}$ North and South of the Equator (FAO, 2004). Aflatoxin is also associated with some chronic health risks, such as cancer, immune suppression, and child stunting (Gong et al., 2016; Leroy, 2013).

Aflatoxin is highly regulated through international trade standards and contamination of agricultural products impacts negatively on trade. Wu (2004) showed that losses in groundnut export from rejected products due to aflatoxin contamination may exceed 450 million US dollars under the current European Union (EU) regulatory standard of $4 \mu \mathrm{g} / \mathrm{kg}$. However, a risk assessment of aflatoxin in food in Africa conducted by Shephard (2008) indicated that even low levels of contamination, which might fall within regulatory limits, can have serious health implications due to high per capita consumption of aflatoxin-prone crops such as maize. Thus, meeting the regulatory limits set for maximum tolerable limits in products destined for human consumption does not in itself guarantee food safety, especially where these products are consumed in relatively large quantities.

Maximum tolerable limits of aflatoxins in food destined for human consumption vary depending on the country (FAO, 2004). The current maximum tolerable limits for aflatoxins in maize and groundnut in the EU, the East African Community (EAC) and the USA are 4, 10 and $20 \mu \mathrm{g} / \mathrm{kg}$, respectively (EC, 2010; USFDA, 2015; EAC, 2011). Intake of high doses of aflatoxins can lead to acute conditions such as aflatoxicosis outbreaks and death. Consumption of food with high levels of aflatoxin can be fatal, as experienced in Kenya in 2004, where 125 people lost their lives after consuming food made from homegrown maize that contained high levels of aflatoxins (Lewis et al., 2005). Tanzania experienced its first cases of acute aflatoxicosis in 2016, when 68 people were hospitalised after consuming contaminated maize and 20 lost their lives (Kamala et al., 2018).

Aflatoxicosis and chronic health risks due to aflatoxin are from dietary exposure. The World Health Organization (WHO) (2018) reports that most human exposure to aflatoxin comes from nuts and grains. Aflatoxin contamination levels can vary widely, from products that meet the maximum tolerable levels set by authorities to products with levels that can pose a risk of acute aflatoxicosis. However, the consumption pattern of a given crop significantly influences aflatoxin-related problems (Gong et al., 2016), thus, low concentration of aflatoxin in a product does not by itself guarantee its safety if the consumption rate per day is high. Maize and groundnut are among the most important food crops in sub-Saharan Africa with high consumption rates per day and are major ingredients in weaning food given to children (Gong et al., 2016). Moreover, children are reported to be more prone to aflatoxicosis than adults because of their less developed immune systems and high intake of foods and water per kg body weight (bw) (Lombard, 2014; WHO, 2018). In Tanzania, maize consumption rate is estimated at 429.4 g/person/day (Abt Associates, 2012), while the Tanzanian Food and Nutrition Center (TFNC) has recommended an average consumption rate of $771 \mathrm{~g} /$ person/day (TFNC, 2014). For groundnut, consumption rate is $15 \mathrm{~g} /$ person/ day (Abt Associates, 2012). Using consumption rate, dietary exposure is calculated to measure parameters such as probable daily intake (PDI), average probable daily intake (APDI) and maximum probable daily intake (MPDI), and these are expressed in $\mathrm{ng} / \mathrm{kg}$ bw/day (Herrman and Yunes, 1999). Estimates of mean aflatoxin dietary exposures in developed countries are generally less than $1 \mathrm{ng} / \mathrm{kg}$ bw/day whereas in some of the countries in sub-Saharan African exceeds $100 \mathrm{ng} / \mathrm{kg}$ bw/day (WHO, 2018).

Aflatoxin contamination of agricultural products starts while the crop is in the field (pre-harvest) and continues through processing, transportation, and storage when environmental conditions are favourable for fungal infection and colonisation (Milani, 2013). Factors favouring aflatoxin contamination include drought during crop growing period, crop contact with bare soil (during harvesting), high temperature and humidity (harvesting and/or storing wet/humid crops) (Schroeder, 1969). As aflatoxins are colourless, odourless and cannot be seen, the only way to detect them is through laboratory testing. However, aflatoxin assaying kits suitable for field testing are either unavailable or expensive for smallholder farmers. This complicates efforts to remove contaminated products, especially for developing countries like Tanzania, where more than $70 \%$ of maize and groundnut production is by smallholder farmers and for home consumption.

Relatively little information on the prevalence of mycotoxins across the maize and groundnut value chains in Tanzania is available (Abt Associates, 2012). A few studies focusing on a few villages and using a limited number of samples have revealed high levels of aflatoxin contamination of maize and groundnuts (Kimanya et al., 2014), and the presence of aflatoxins in milk and serum (Magoha et al., 2014a; Shirima et al., 2013). Assessing mycotoxin contamination of maize and groundnuts across a wide area of Tanzania encompassing several agro-ecological zones is the first and essential step in addressing the problem. This study was conducted to quantify aflatoxin contamination in maize and groundnuts across the major producing regions in Tanzania. This information was necessary for selection of areas to target intervention strategies for managing aflatoxin and for targeting aflatoxin awareness raising activities. Previous reports revealed that awareness of aflatoxin and its health impacts is low in Tanzania (Kimanya et al., 2014; Magembe et al., 2016; Nathaniels, 2014; TFDA, 2012). 


\section{Materials and methods}

\section{Selection of sites to collect samples}

Information on history and levels of maize and groundnut production was obtained from a stakeholders' inception workshop that was held between 18-19 April 2012 at IITA campus in Dar es Salaam, Tanzania. Priority study areas were based on where there had been reports of aflatoxin and/or food poisoning and where maize and groundnut were predominantly cultivated. This information was used to select 18 districts across Tanzania that were targeted for sample collection (Supplementary Figure S1), and to assess levels of aflatoxin awareness among stakeholders along the maize and groundnut value chains using a questionnaire.

\section{Sample collection}

With International Institute of Tropical Agriculture (IITA) leading the activities, Ministry of Agriculture (MA) in Tanzania, Tanzania Food and Drugs Authority (TFDA), Sokoine University of Agriculture (SUA) and Tropical Pesticide Research Institute (TPRI) worked together as a team to collect samples in the country. Ten villages which were at least $10 \mathrm{~km}$ apart were randomly selected for each district. For groundnuts, $0.5 \mathrm{~kg}$ of grain was collected from each participating farmer, while a $1 \mathrm{~kg}$ sample was collected for maize. Depending on availability, one or two samples were collected per village for each crop. Samples were collected from farmer fields, storage structures and markets. In Tanzania, farmers normally store their maize or groundnut in $90 \mathrm{~kg}$ sacks or containers in granaries. Samples were collected from the top, middle and bottom of the storage container and mixed together to provide a single sample of 1 and $0.5 \mathrm{~kg}$ for maize and groundnut respectively for laboratory analysis. A total of 200 maize and 180 groundnut samples were collected. For each collected sample, moisture content was measured, and if the moisture content was $>13 \%$, the samples were further dried in an oven at $90{ }^{\circ} \mathrm{C}$ until desired moisture content. Before analysis, samples were stored at $-20{ }^{\circ} \mathrm{C}$ to avoid fungal growth. Socioeconomic data that included information on whether the responding households were aware of mycotoxins, level of education and economic status was collected using a questionnaire. GPS coordinates were recorded at each sampling site.

\section{Extraction and purification of aflatoxin from samples}

The entire $1 \mathrm{~kg}$ maize grain sample was ground to pass a 10-micron sieve using BUNN ${ }^{\text {sM }}$ grinder (Bunn-O-Matic Corporation Springfield, IL, USA). For groundnut, the entire $0.5 \mathrm{~kg}$ sample was milled using Waring laboratory blender (Waring Lab, Torrington, CT, USA). The flour for each sample was thoroughly mixed and sub-sampled using a sequential quartering technique to obtain $20 \mathrm{~g}$ sample for analysis. The rest of the sample was placed in a Ziplock plastic bag and stored at $-20^{\circ} \mathrm{C}$. Aflatoxins were extracted by placing $20 \mathrm{~g}$ sample in a $100 \mathrm{ml}$ glass bottle containing $50 \mathrm{ml}$ of acetonitrile and water $(3: 1, \mathrm{v} / \mathrm{v})$; placed on a horizontal shaker and shaken at $140 \mathrm{rpm}$ for $50 \mathrm{~min}$. The solution was passed through two layers of Whatman filter paper No. 1 (Whatman, Maidstone, UK); $4 \mathrm{ml}$ of the filtrate were adjusted to $\mathrm{pH} 7$ using $0.1 \mathrm{M} \mathrm{NaOH}$ solution, diluted with $36 \mathrm{ml}$ of phosphate buffer saline solution $(\mathrm{pH}$ $7.4 \mathrm{NaCl} 0.15 \mathrm{M}$ ). The diluted extract was passed through AflaStar immunoaffinity column (Romer Labs, Getzersdorf, Austria) fitted to a solid-phase extraction manifold and allowed to flow through without application of vacuum. The columns were washed with $25 \mathrm{ml}$ of sterile distilled water, and aflatoxins were eluted under vacuum using $3 \mathrm{ml}$ of methanol, applied as $0.5-\mathrm{ml}$ aliquots which were held in the bed for $3 \mathrm{~min}$.

\section{Aflatoxin analysis}

Aflatoxins were quantified using high-performance liquid chromatography (HPLC) (Stroka et al., 2000). Briefly, an aliquot of $20 \mu \mathrm{l}$ of elute was injected into the reverse-phase HPLC and analysed using a fluorescence detection system without derivatization of the aflatoxins (Samapundo et al., 2007). A Waters HPLC system (Waters, Milford, MA, USA) consisting of a Waters 600 pump and controller was used and the system was connected to an auto-injector (Shimadzu RF-10AXL florescence detector and Shimadzu C-R 3A chromatopac integrator; Shimadzu, Tokyo, Japan). Chromatographic separations were performed on a Bondapak ODS column $(250 \times 4.6 \mathrm{~mm}, 5 \mu \mathrm{m}$ pore size; Waters). A methanol/water mixture $(1: 1, \mathrm{v} / \mathrm{v})$ was used as mobile phase. The flow rate of the mobile phase was set at $0.7 \mathrm{ml} / \mathrm{min}$.

Fluorescence of the aflatoxins was recorded at wavelengths of $360 \mathrm{~nm}$ (excitation) and $440 \mathrm{~nm}$ (emission). The limit of detection of the analytical method was $0.6 \mu \mathrm{g} / \mathrm{kg}$ for $\mathrm{AFB}_{1}$ and aflatoxin $G_{1}\left(A_{F} G_{1}\right)$, and $0.07 \mu \mathrm{g} / \mathrm{kg}$ for aflatoxin $B_{2}$ $\left(\mathrm{AFB}_{2}\right)$ and aflatoxin $\mathrm{G}_{2}\left(\mathrm{AFG}_{2}\right)$. To assess the repeatability of the method, aflatoxin free maize and groundnut samples were spiked with $\mathrm{AFB}_{1}$ and $\mathrm{AFG}_{1}$ pure toxins, each at three concentrations $0.76 \mu \mathrm{g} / \mathrm{kg}, 3.81 \mu \mathrm{g} / \mathrm{kg}$, and $6.85 \mu \mathrm{g} / \mathrm{kg}$. The recovery rate was $89 \%$ for $\mathrm{AFB}_{1}$ and $\mathrm{AFG}_{1}$. Similarly, blank maize and groundnut samples were also spiked with pure $\mathrm{AFB}_{2}$ and $\mathrm{AFG}_{2}$ toxins, each at a concentration of $0.56 \mu \mathrm{g} /$ $\mathrm{kg}, 1.31 \mu \mathrm{g} / \mathrm{kg}$, and $1.675 \mu \mathrm{g} / \mathrm{kg}$ and the average recovery rate was $87 \%$. The aflatoxin concentrations obtained from HLPC were corrected for recovery rate.

\section{Dietary exposure}

Three parameters (PDI, APDI) and maximum probable daily intake (MPDI)) were used to assess dietary exposure level to aflatoxins. PDI and APDI estimates were calculated as described by Herrman and Yunes (1999) as follows: 
1. $\mathrm{PDI}(\mathrm{ng} / \mathrm{kg}$ bw/day $)=$ maize intake $(\mathrm{g} /$ person/day $) \times$ levels of aflatoxins in the samples $(\mu \mathrm{g} / \mathrm{kg}) / \mathrm{bw}(\mathrm{kg})$;

2. APDI $(\mathrm{ng} / \mathrm{kg}$ bw/day $)=$ maize intake $(\mathrm{g} /$ person/day $) \times$ average aflatoxin concentrations in the samples $(\mu \mathrm{g} / \mathrm{kg}) /$ bw $(\mathrm{kg})$.

The estimates of the maximum probable daily intake (MPDI) of aflatoxin were calculated using the formula:

\section{3. $\operatorname{MPDI}(\mathrm{ng} / \mathrm{kg}$ bw/day $)=(\mathrm{L} \times \mathrm{D}) / \mathrm{bw}(\mathrm{kg})$.}

where $\mathrm{L}$ is the $90^{\text {th }}$ percentile concentration of aflatoxin in the samples; and D the daily consumption of maize based foods (g/person/day). For all estimates, the assumed typical body weight of an adult was $60 \mathrm{~kg}$. Different consumption scenarios were used to estimate exposure to aflatoxins. Based on a study by Abt Associates (2012), consumption levels were assumed to be different for different regions and these were used to estimate exposure for each region. An average consumption rate (based on FAO) and a third scenario based on recommendations from Tanzania Food and Nutrition Center (TFNC, 1997) were also used.

\section{Statistical analysis}

Statistical analysis was done using SAS (SAS Institute Inc., Cary, NC, USA) version 9.4 for Windows for hypothesis testing using T-test and calculation of average, median and $90^{\text {th }}$ percentile values. Total aflatoxin was derived as a summation of $\mathrm{AFB}_{1}, \mathrm{AFB}_{2}, \mathrm{AFG}_{1}$ and $\mathrm{AFG}_{2}$. OneSample t-test after $\log 10(\mathrm{x}+1)$ transformation was used to determine the variation of aflatoxin prevalence across districts. The data for the levels of contamination of aflatoxin were analysed using ANOVA. The means were separated by Student-Newman-Keuls Test (SNK) to assess differences in aflatoxin prevalence and quantity between districts. Chi-Square analysis was used to compare the proportion of samples with aflatoxin levels above maximum tolerable limits set for EAC $(10 \mu \mathrm{g} / \mathrm{kg})$ and EU $(4 \mu \mathrm{g} / \mathrm{kg})$. Unless otherwise stated, all statistical tests were judged significant at $P=0.05$.

\section{Results}

\section{Levels of aflatoxin awareness}

The level of aflatoxin awareness among stakeholders interviewed ranged from 5 to $95 \%$ with an average of $75 \%$ of people interviewed not aware of aflatoxins (Figure 1). Most farmers interviewed were unaware of aflatoxins, the health impacts from consumption of aflatoxin contaminated food, and strategies to minimise contamination. Some districts, such as Babati (90\%), Masasi (95\%) and Nanyumbu (95\%) had exceptionally high percentage of farmers who were aware of aflatoxins (Figure 1). In contrast, farmers interviewed in eight of the 18 districts studied were not aware of aflatoxin, and in another five districts, less than $10 \%$ were aware of aflatoxins (Figure 1 ). More groundnut farmers $(30.1 \pm 13.8 \%)$ were aware of aflatoxins compared to maize farmers $(14.5 \pm 9.5 \%)$ (Figure 1$)$.

\section{Prevalence of aflatoxins}

\section{Groundnut}

From a total of 180 groundnut samples collected, aflatoxins were detected in 173 (96.1\%) (Table 1). Aflatoxin prevalence in districts ranged between $90 \%$ and $100 \%$, and all samples from four districts (Babati, Chamwino, Kahama and Nzega) contained detectable aflatoxin levels (Table 1). Of the aflatoxin positive samples, 55 (31\%) contained aflatoxin levels above the maximum tolerable limit set by the EU $(4 \mu \mathrm{g} / \mathrm{kg})$, while 31 samples $(17 \%)$ contained aflatoxin levels exceeding the EAC and Tanzanian maximum tolerable limit of $10 \mu \mathrm{g} / \mathrm{kg}$ for total aflatoxins (Table 1). No significant differences were observed in the number of groundnut samples testing positive for aflatoxin $(P>0.05)$ between districts (Table 1). $\mathrm{AFB}_{1}$ was detected in $134(74.4 \%)$ of the 180 samples (Table 2).

\section{Maize}

In comparison to groundnut, fewer maize samples had detectable aflatoxin levels. Of the 200 samples collected, 99 (49.5\%) had detectable aflatoxins and prevalence ranged from 10 to $80 \%$ (Table 3). Significant differences $(P \leq 0.001)$ were observed in the number of aflatoxin positive samples in districts; Babati, Ifakara, Kilosa, Kiteto and Sumbawanga having more than $50 \%$ of the samples testing positive for aflatoxins (Table 3). Districts with samples containing total aflatoxin levels exceeding the European Union regulatory limit of $4 \mu \mathrm{g} / \mathrm{kg}$ and EAC regulatory limit of $10 \mu \mathrm{g} / \mathrm{kg}$ (respectively) were Babati (20\% for both limits), Ifakara (35\% and 30\%), Kilosa (55\% for both limits) and Kiteto (5\% for both limits). Overall, $12 \%$ of the maize samples exceeded the EU regulatory limit of $4 \mu \mathrm{g} / \mathrm{kg}$, while $11 \%$ exceeded the EAC and Tanzanian regulatory limit of $10 \mu \mathrm{g} / \mathrm{kg}$ for total aflatoxin (Table 3). $\mathrm{AFB}_{1}$ was detected in 45 (22.5\%) samples but was not detected in samples from two districts: Makambako and Mbinga (Table 4).

\section{Aflatoxin levels}

\section{Groundnut}

Average aflatoxin levels in groundnut samples ranged from 2.50 to $10.93 \mu \mathrm{g} / \mathrm{kg}$, with an overall mean of $6.37 \mu \mathrm{g} / \mathrm{kg}$ (Table 1). Median aflatoxin levels ranged from $1.24 \mu \mathrm{g} / \mathrm{kg}$ in Nzenga district to $6.39 \mu \mathrm{g} / \mathrm{kg}$ in Iringa Rural district. No significant differences were observed in levels of total aflatoxin $(\mathrm{F}=1.66 ; P=0.111)$ contamination between 


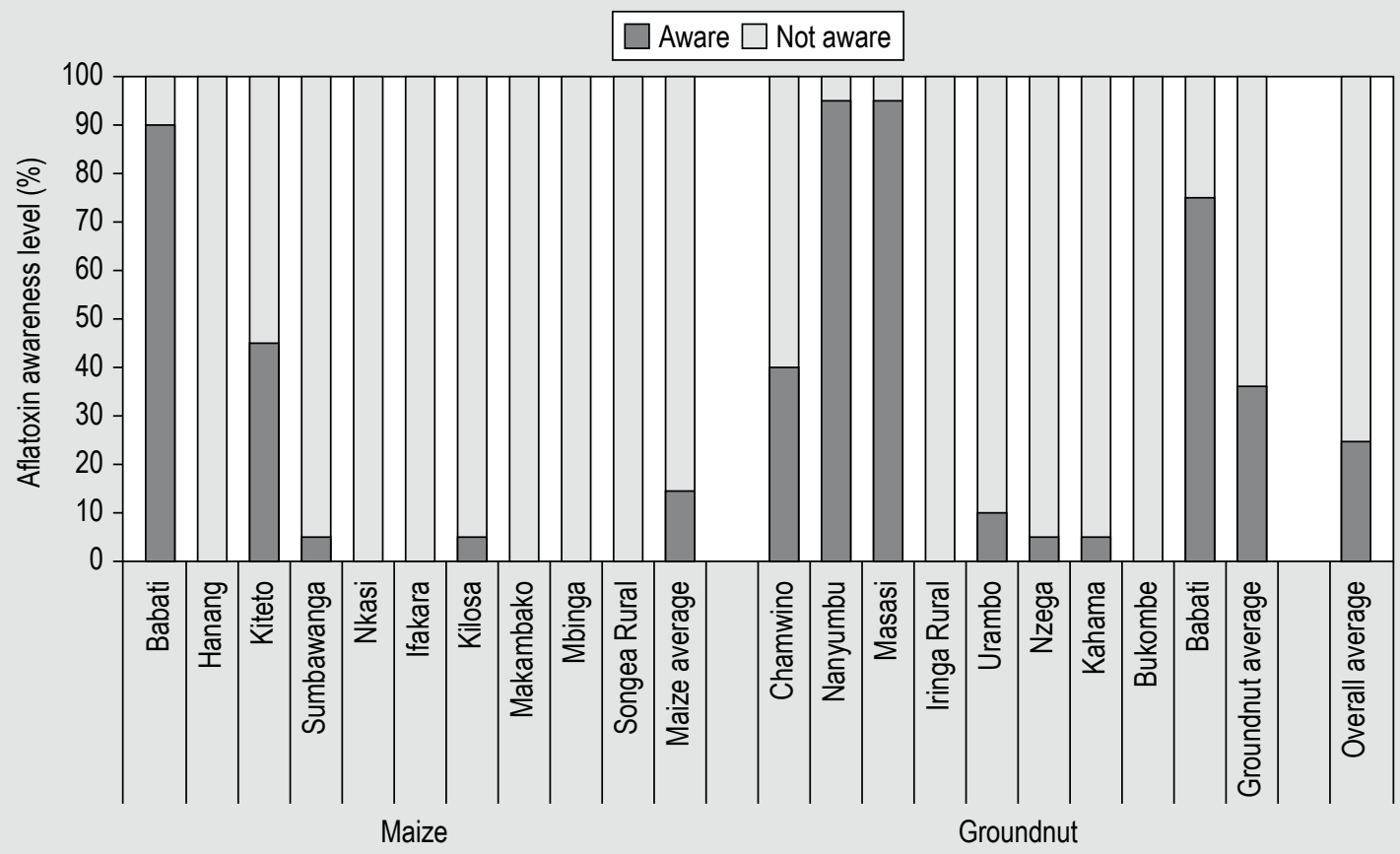

District and crop

Figure 1. Proportion of aflatoxin-aware farmers who provided maize and groundnut samples in 18 districts of Tanzania in 2012 assessed based on questionnaire.

Table 1. Prevalence and levels of total aflatoxin in groundnut collected from nine districts in Tanzania in 2012 and proportion of groundnut samples with total aflatoxin levels exceeding maximum tolerable limits in the European Union (EU) and East African Community (EAC).

\begin{tabular}{|c|c|c|c|c|c|c|c|}
\hline District & $\begin{array}{l}\text { Number (n) } \\
\text { of samples }\end{array}$ & $\begin{array}{l}\text { Positive } \\
\text { samples N (\%) }\end{array}$ & $\begin{array}{l}\text { Concentration } \\
\text { range of positive } \\
\text { samples }(\mu \mathrm{g} / \mathrm{kg})\end{array}$ & $\begin{array}{l}\text { Median } \\
(\mu \mathrm{g} / \mathrm{kg})\end{array}$ & $\begin{array}{l}\text { Mean }(\mu \mathrm{g} / \mathrm{kg}) \pm \\
\text { standard error }^{1}\end{array}$ & $\begin{array}{l}\text { Number of samples } \\
\text { exceeding EU } \\
\text { regulatory limit of } \\
4 \mu \mathrm{g} / \mathrm{kg}(\%)\end{array}$ & $\begin{array}{l}\text { Number of samples } \\
\text { exceeding EAC } \\
\text { regulatory limit of } \\
10 \mu \mathrm{g} / \mathrm{kg}(\%)\end{array}$ \\
\hline Babati & 20 & $20(100)$ & $1.42-40.31$ & 4.01 & $7.69 \pm 2.25^{a}$ & $10(50)$ & $3(15)$ \\
\hline Bukombe & 20 & $19(95)$ & $0.90-30.07$ & 2.75 & $7.63 \pm 2.29 a$ & $6(30)$ & $4(20)$ \\
\hline Chamwino & 20 & $20(100)$ & $0.08-23.60$ & 1.42 & $3.25 \pm 1.17^{a}$ & $4(20)$ & $1(5)$ \\
\hline Iringa Rural & 20 & $18(90)$ & $0.51-36.09$ & 6.39 & $10.93 \pm 2.91^{a}$ & $10(50)$ & $6(30)$ \\
\hline Kahama & 20 & $20(100)$ & $1.10-33.59$ & 2.89 & $6.10 \pm 1.95^{a}$ & $5(25)$ & $3(15)$ \\
\hline Masasi & 20 & $18(90)$ & $0.08-37.54$ & 2.91 & $8.15 \pm 2.41^{a}$ & $7(35)$ & $5(25)$ \\
\hline Nanyumbu & 20 & $19(95)$ & $0.06-32.44$ & 2.35 & $7.03 \pm 2.39^{a}$ & $5(25)$ & $4(20)$ \\
\hline Nzenga & 20 & $20(100)$ & $0.04-18.42$ & 1.24 & $4.60 \pm 1.38^{a}$ & $6(30)$ & $4(20)$ \\
\hline Urambo & 20 & $19(95)$ & $0.34-14.74$ & 1.46 & $2.50 \pm 0.73^{a}$ & $2(10)$ & $1(5)$ \\
\hline All samples & 180 & $173(96.1)$ & $0.04-40.31$ & 2.57 & $6.37 \pm 0.68$ & $55(30.6)$ & $31(17)$ \\
\hline
\end{tabular}

${ }^{1}$ Means with same letter(s) are not significantly different at the 0.05 level.

districts. The highest contaminated sample contained 40.31 $\mu \mathrm{g} / \mathrm{kg}$ aflatoxins and this sample was from Babati (Table 1 ). Average $\mathrm{AFB}_{1}$ levels ranged from 1.01 to $9.02 \mu \mathrm{g} / \mathrm{kg}$, with a mean of $5.02 \mu \mathrm{g} / \mathrm{kg}$ and a median of $0.58 \mu \mathrm{g} / \mathrm{kg}$ (Table $2)$. The highest contaminated sample contained $38.32 \mu \mathrm{g} /$ $\mathrm{kg} \mathrm{AFB}_{1}$ and this sample was from Babati. No significant differences $(\mathrm{F}=1.16 ; P=0.327)$ were observed for levels of $\mathrm{AFB}_{1}$ between districts (Table 2).

\section{Maize}

Average aflatoxin levels between districts ranged from 0.96 to $44.11 \mu \mathrm{g} / \mathrm{kg}$ with an overall mean of $12.47 \mu \mathrm{g} / \mathrm{kg}$ (Table 3). Significant differences $(\mathrm{F}=4.98 ; P<0.001)$ in levels of aflatoxin contamination were observed between districts, with Kilosa (average $44.11 \mu \mathrm{g} / \mathrm{kg}$ ) and Ifakara (average 25.89 $\mu \mathrm{g} / \mathrm{kg}$ ) having high levels of contamination compared to 
Table 2. Prevalence, consumption, concentration, probable daily intake (PDI), average probable daily intake (APDI) and maximum probable daily intake (MPDI) of aflatoxin $\mathrm{B}_{1}\left(\mathrm{AFB}_{1}\right)$ in groundnut consumed in different districts of Tanzania. ${ }^{1}$

\begin{tabular}{|c|c|c|c|c|c|c|c|c|c|}
\hline District & $\begin{array}{l}\text { Number } \\
\text { (n) of } \\
\text { samples }\end{array}$ & $\begin{array}{l}\text { Positive } \\
\text { samples } \\
\mathrm{N}(\%)\end{array}$ & $\begin{array}{l}\text { Mean AFB }_{1} \\
(\mu \mathrm{g} / \mathrm{kg}) \pm \\
\text { standard error }^{2}\end{array}$ & $\begin{array}{l}\text { Concentration } \\
\text { range of positive } \\
\text { samples }(\mu \mathrm{g} / \mathrm{kg})\end{array}$ & $\begin{array}{l}90^{\text {th }} \\
\text { percentile } \\
(\mu \mathrm{g} / \mathrm{kg})\end{array}$ & $\begin{array}{l}\text { Consumption } \\
\text { (g/person/day) }\end{array}$ & $\begin{array}{l}\text { PDI range ng/ } \\
\text { kg bw/day }{ }^{4}\end{array}$ & $\begin{array}{l}\text { APDI } \\
\text { ng/kg } \\
\text { bw/day } 4\end{array}$ & 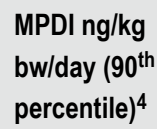 \\
\hline Babati & 20 & $14(70)$ & $6.43 \pm 3.02^{\mathrm{a}}$ & $0.37-38.30$ & 21.6 & 3.2 & $0.019-2.044$ & 0.343 & 1.150 \\
\hline Bukombe & 20 & $14(70)$ & $6.21 \pm 2.35^{\mathrm{a}}$ & $0.39-22.80$ & 18.7 & 29.7 & $0.193-11.261$ & 3.074 & 9.276 \\
\hline Chamwino & 20 & $16(80)$ & $2.70 \pm 1.40^{\mathrm{a}}$ & $0.27-22.80$ & 6.6 & 36.4 & $0.164-13.832$ & 1.637 & 4.028 \\
\hline Iringa Rural & 20 & $16(80)$ & $9.02 \pm 2.72^{\mathrm{a}}$ & $0.28-32.90$ & 25.3 & 14.1 & $0.066-7.732$ & 2.120 & 5.936 \\
\hline Kahama & 20 & $16(80)$ & $4.41 \pm 2.11^{\mathrm{a}}$ & $0.37-30.80$ & 16. 6 & 29.8 & $0.183-15.221$ & 2.184 & 8.197 \\
\hline Masasi & 20 & $15(75)$ & $4.84 \pm 2.22^{\mathrm{a}}$ & $0.37-31.00$ & 15.2 & 15.1 & 0.093-7.794 & 1.218 & 3.823 \\
\hline Nanyumbu & 20 & $16(80)$ & $5.55 \pm 2.43^{a}$ & $0.37-30.10$ & 22.6 & 15.1 & $0.093-7.585$ & 1.397 & 5.655 \\
\hline Nzega & 20 & $11(55)$ & $5.52 \pm 1.90^{\mathrm{a}}$ & $0.26-17.10$ & 13.7 & 29.7 & $0.129-8.460$ & 2.730 & 6.796 \\
\hline Urambo & 20 & $16(80)$ & $1.01 \pm 0.54^{a}$ & $0.26-9.10$ & 1.1 & 29.7 & $0.129-4.480$ & 0.498 & 0.530 \\
\hline All samples & 180 & $134(74.4)$ & $5.02 \pm 0.73$ & $0.26-38.30$ & 18.7 & 22.5 & $0.098-14.370$ & 1.884 & 7.028 \\
\hline
\end{tabular}

\footnotetext{
${ }^{1} \mathrm{AFB}_{1}$ is a genotoxic carcinogen, as such, a tolerable daily intake has not been set. Rather, the ALARA principle (As Low As Reasonably Achievable) is recommended.

${ }^{2}$ Means with same letter(s) are not significantly different at 0.05 level.

${ }^{3}$ Groundnut consumption adopted from the report by Abt (2014).

${ }^{4}$ Body weight (bw) is $60 \mathrm{~kg}$.
}

Table 3. Prevalence of total aflatoxin in maize collected from ten districts of Tanzania in 2012 and proportion of maize samples with aflatoxin levels exceeding maximum tolerable limits in the European Union (EU) and East African Community (EAC).

\begin{tabular}{|c|c|c|c|c|c|c|}
\hline District & $\begin{array}{l}\text { Number }(n) \\
\text { of samples }\end{array}$ & $\begin{array}{l}\text { Positive } \\
\text { samples N (\%) }\end{array}$ & $\begin{array}{l}\text { Median } \\
(\mu \mathrm{g} / \mathrm{kg})\end{array}$ & $\begin{array}{l}\text { Mean of positive samples } \\
\pm \text { standard error }(\mu \mathrm{g} / \mathrm{kg})^{1}\end{array}$ & $\begin{array}{l}\text { Percent of samples } \\
\text { exceeding EU regulatory } \\
\text { limit of } 4 \mu \mathrm{g} / \mathrm{kg} \mathrm{N}(\%)\end{array}$ & $\begin{array}{l}\text { Percent of samples } \\
\text { exceeding EAC regulatory } \\
\text { limit of } 10 \mu \mathrm{g} / \mathrm{kg}: \mathrm{n}(\%)\end{array}$ \\
\hline Babati & 20 & $14(70)$ & 1.68 & $7.15 \pm 2.68^{a}$ & $4(20)$ & $4(20)$ \\
\hline Hanang & 20 & $5(25)$ & 0.99 & $0.96 \pm 0.29^{a}$ & $0(0)$ & $0(0)$ \\
\hline Ifakara & 20 & $14(70)$ & 4.39 & $25.87 \pm 9.20^{b}$ & $7(35)$ & $6(30)$ \\
\hline Kilosa & 20 & $16(80)$ & 31.26 & $44.11 \pm 11.96^{b}$ & $11(55)$ & $11(55)$ \\
\hline Kiteto & 20 & $13(65)$ & 0.07 & $1.67 \pm 1.44^{\mathrm{a}}$ & $1(5)$ & $1(5)$ \\
\hline Makambako & 20 & $9(45)$ & 0.97 & $0.97 \pm 0.13^{a}$ & $0(0)$ & $0(0)$ \\
\hline Mbinga & 20 & $2(10)$ & 1.27 & $1.27 \pm 0.24^{a}$ & $0(0)$ & $0(0)$ \\
\hline Nkasi & 20 & $7(35)$ & 1.20 & $1.40 \pm 0.32^{\mathrm{a}}$ & $0(0)$ & $0(0)$ \\
\hline Songea & 20 & $6(30)$ & 0.97 & $1.21 \pm 0.24^{a}$ & $0(0)$ & $0(0)$ \\
\hline Sumbawanga & 20 & $13(65)$ & 0.52 & $0.92 \pm 0.29^{a}$ & $0(0)$ & $0(0)$ \\
\hline All samples & 200 & 99 (49.5) & 1.14 & $12.48 \pm 2.82$ & $23(11.5)$ & $22(11)$ \\
\hline
\end{tabular}

${ }^{1}$ Means with same letter(s) in a column are not significantly different at 0.05 level.

other districts (Table 3). Six of the districts contained low levels of aflatoxin, below the EU regulatory limit of $4 \mu \mathrm{g} /$ $\mathrm{kg}$. The maximum level of aflatoxin was detected in Kilosa $(162.40 \mu \mathrm{g} / \mathrm{kg})$ followed by Ifakara $(92.47 \mu \mathrm{g} / \mathrm{kg})($ Table 5$)$. $\mathrm{AFB}_{1}$ levels in maize samples ranged between 0.46 and $159.54 \mu \mathrm{g} / \mathrm{kg}$, with a mean of $21.24 \mu \mathrm{g} / \mathrm{kg}$ and a median of $2.60 \mu \mathrm{g} / \mathrm{kg}$ (Table 4). High levels of $\mathrm{AFB}_{1}$ were observed in
Kilosa (mean $44.08 \mu \mathrm{g} / \mathrm{kg}$; range 1.09-159.54 $\mu \mathrm{g} / \mathrm{kg}$ ), Ifakara (mean $=27.38 \mu \mathrm{g} / \mathrm{kg}$; range 0.6-91.15 $\mu \mathrm{g} / \mathrm{kg}$ ) and Babati (mean $=12.86 \mu \mathrm{g} / \mathrm{kg}$; range $0.60-23.48 \mu \mathrm{g} / \mathrm{kg}$ ) compared to the other districts. $\mathrm{AFB}_{1}$ levels in the highly contaminated sample was $159.54 \mu \mathrm{g} / \mathrm{kg}$, which was 30 -fold more than the level $(5 \mu \mathrm{g} / \mathrm{kg})$ recommended by EAC and TBS for maize destined for human consumption. 
Table 4. Prevalence, concentration, probable daily intake (PDI)and average probable daily intake (APDI) of aflatoxin $B_{1}\left(A_{F B}\right)$ in maize consumed in different districts of Tanzania.

\begin{tabular}{|c|c|c|c|c|c|c|c|c|c|c|c|}
\hline \multirow[t]{2}{*}{ District } & \multirow[t]{2}{*}{$\begin{array}{l}\text { Number } \\
\text { (n) of } \\
\text { samples }\end{array}$} & \multirow[t]{2}{*}{$\begin{array}{l}\text { Positive } \\
\text { samples } \\
\mathrm{n}(\%)\end{array}$} & \multirow{2}{*}{$\begin{array}{l}\text { Mean AFB } \\
(\mu \mathrm{g} / \mathrm{kg}) \pm \\
\text { standard } \\
\text { error }^{1}\end{array}$} & \multirow{2}{*}{$\begin{array}{l}\mathrm{AFB}_{1} \\
\text { concentration } \\
\text { range }(\mu \mathrm{g} / \mathrm{kg})\end{array}$} & \multirow{2}{*}{$\begin{array}{l}90^{\text {th }} \\
\text { percentile } \\
\text { concentration } \\
(\mu \mathrm{g} / \mathrm{kg})\end{array}$} & \multicolumn{2}{|c|}{ PDI range (ng/kg bw/day) ${ }^{2,3}$} & \multicolumn{2}{|c|}{$\begin{array}{l}\text { APDI (ng/kg } \\
\text { bw/day) })^{2,3}\end{array}$} & \multicolumn{2}{|c|}{$\begin{array}{l}\text { MPDI (ng/kg } \\
\text { bw/day } 90^{\text {th }} \\
\text { percentile })^{2,3}\end{array}$} \\
\hline & & & & & & Abt & TFNC & Abt & TFNC & Abt & TFNC \\
\hline Babati & 20 & $6(30)$ & $12.86 \pm 3.95^{\mathrm{ab}}$ & $0.60-23.48$ & 23.48 & $4.29-168.07$ & 7.71-301.77 & 92.05 & 165.28 & 168.07 & 301.77 \\
\hline Hanang & 20 & $1(5)$ & $0.63 \pm 0.00^{\mathrm{b}}$ & & - & 4.50 & 8.08 & 4.50 & 8.08 & 4.50 & 8.08 \\
\hline Ifakara & 20 & $12(60)$ & $27.38 \pm 9.74^{a}$ & $0.60-91.15$ & 77.35 & $4.29-652.36$ & $7.71-1,171.33$ & 195.93 & 351.81 & 553.60 & 994.00 \\
\hline Kilosa & 20 & $12(60)$ & $44.08 \pm 13.70^{\mathrm{a}}$ & $1.09-159.54$ & 96.70 & $7.80-1,141.80$ & $14.00-2,050.10$ & 315.48 & 566.46 & 692.05 & $1,242.60$ \\
\hline Kiteto & 20 & $3(15)$ & $4.44 \pm 3.85^{b}$ & $0.48-12.13$ & 12.13 & $3.41-86.82$ & 6.13-155.88 & 31.74 & 56.99 & 86.82 & 155.88 \\
\hline Makambako & 20 & $0(0)$ & - & - & - & - & - & - & - & - & - \\
\hline Mbinga & 20 & $0(0)$ & - & - & - & - & - & - & - & - & - \\
\hline Nkasi & 20 & $4(20)$ & $0.68 \pm 0.04^{b}$ & $0.61-0.77$ & 0.71 & $4.37-5.51$ & $7.84-9.89$ & 4.87 & 8.74 & 5.51 & $9.8 \mathrm{~s}$ \\
\hline Songea & 20 & $1(5)$ & $0.99 \pm 0.00^{b}$ & 0.99 & 0.99 & 7.14 & 12.81 & 7.14 & 12.81 & 7.14 & 12.81 \\
\hline Sumbawanga & 20 & $6(30)$ & $0.55 \pm 0.03^{b}$ & $0.456-0.63$ & 0.63 & $3.26-4.53$ & $5.86-8.13$ & 3.94 & 7.07 & 4.53 & 8.13 \\
\hline Average & 200 & $45(22.5)$ & $21.24 \pm 5.07$ & $0.46-159.54$ & 77.35 & $3.26-1,141.78$ & $5.86-2,050.1$ & 151.98 & 272.89 & 553.60 & 994.00 \\
\hline
\end{tabular}

Table 5. Concentration, probable daily intake (PDI), average probable daily intake (APDI) and maximum probable daily intake (MPDI) of total aflatoxin in maize from different districts of Tanzania.

\begin{tabular}{|c|c|c|c|c|c|c|c|c|c|}
\hline \multirow[t]{2}{*}{ District } & \multirow[t]{2}{*}{$\begin{array}{l}\text { Concentration } \\
\text { range of positive } \\
\text { samples }(\mu \mathrm{g} / \mathrm{kg} \text { ) }\end{array}$} & \multirow{2}{*}{$\begin{array}{l}\text { Mean } \\
\text { concentration of } \\
\text { positive samples } \\
(\mu \mathrm{g} / \mathrm{kg})\end{array}$} & \multirow{2}{*}{$\begin{array}{l}90^{\text {th }} \text { percentile } \\
\text { concentration } \\
\text { of positive } \\
\text { samples }(\mu \mathrm{g} / \mathrm{kg})\end{array}$} & \multicolumn{2}{|c|}{ PDI range (ng/kg bw/day) ${ }^{1}$} & \multicolumn{2}{|c|}{$\begin{array}{l}\text { APDI (ng/kg } \\
\text { bw/day) }{ }^{1}\end{array}$} & \multicolumn{2}{|c|}{$\begin{array}{l}\text { MPDI (ng/kg } \\
\text { bw/day } 90^{\text {th }} \\
\text { percentile) }{ }^{1}\end{array}$} \\
\hline & & & & Abt & TFNC & Abt & TFNC & Abt & TFNC \\
\hline Babati & $0.07-27.50$ & 7.15 & 24.65 & $0.50-196.79$ & $0.90-353.38$ & 51.17 & 91.88 & 176.39 & 316.74 \\
\hline Hanang & $0.08-1.78$ & 0.96 & 1.78 & $0.57-12.74$ & $1.03-22.87$ & 6.87 & 12.34 & 12.72 & 22.83 \\
\hline Ifakara & $0.07-92.47$ & 25.89 & 80.61 & $0.50-661.72$ & $0.90-1,118.24$ & 185.27 & 332.69 & 576.82 & 1035.79 \\
\hline Kilosa & $0.10-162.40$ & 44.11 & 105.92 & $0.72-1,162.13$ & $1.29-2,086.84$ & 315.65 & 566.81 & 757.97 & 1361.08 \\
\hline Kiteto & $0.06-18.88$ & 1.67 & 0.87 & $0.43-135.11$ & $0.77-242.61$ & 11.95 & 21.46 & 6.21 & 11.15 \\
\hline Makambako & $0.08-1.34$ & 0.97 & 1.34 & $0.57-9.59$ & $1.03-17.22$ & 6.94 & 12.46 & 9.60 & 17.24 \\
\hline Mbinga & $1.03-1.51$ & 1.27 & 1.51 & $7.37-10.81$ & $13.24-19.40$ & 9.09 & 16.32 & 10.77 & 19.34 \\
\hline Nkasi & $0.07-2.42$ & 1.40 & 2.42 & $0.50-17.32$ & $0.90-31.10$ & 10.02 & 17.99 & 17.32 & 31.11 \\
\hline Songea & $0.09-2.42$ & 1.21 & 2.42 & $0.64-17.32$ & $1.16-31.10$ & 8.66 & 15.55 & 17.33 & 31.12 \\
\hline Sumbawanga & $0.06-2.70$ & 0.92 & 2.62 & $0.43-19.32$ & $0.77-34.70$ & 6.58 & 11.82 & 18.76 & 33.69 \\
\hline Average & $0.06-162.40$ & 12.48 & 54.99 & $0.43-1,162.24$ & $0.77-2,086.84$ & 89.28 & 160.30 & 393.55 & 706.62 \\
\hline
\end{tabular}

\footnotetext{
${ }^{1}$ Consumption rates: $\mathrm{Abt}=429.4 \mathrm{~g} /$ person $/$ day; TFNC $=771 \mathrm{~g} /$ person $/$ day. Body weight $(\mathrm{bw})$ is $60 \mathrm{~kg}$.
} 


\section{Exposure to aflatoxins}

The probable daily intake of aflatoxins assuming that the maize collected from farmers was destined for consumption ranged between 0.43 and $1,162.24 \mathrm{ng} / \mathrm{kg} \mathrm{bw} /$ day in all districts when using an average maize consumption rate of $429.4 \mathrm{~g} /$ day/person according to method described by Abt Associates (2012). Using the maize consumption rate recommended by the Tanzanian Food and Nutrition Center (TFNC) of $771 \mathrm{~g} /$ person/day, exposure rates were much higher, ranging between 0.77 and 2,086.84 ng/ $/ \mathrm{kg}$ bw/day (Table 5 ). The average probable daily intake ranged between 6.58 and $315.65 \mathrm{ng} / \mathrm{kg}$ bw / day using the Abt average consumption rate of $429.4 \mathrm{~g} / \mathrm{person} /$ day; and from 11.82 to $566.81 \mathrm{ng} / \mathrm{kg}$ bw/day using the TFNC recommended consumption rate of $771 \mathrm{~g} /$ person/day (Table 5). The maximum probable daily intake ranged from 6.21 to $757.97 \mathrm{ng} / \mathrm{kg}$ and from 11.15 to $1,361.08$ $\mathrm{ng} / \mathrm{kg}$ bw/day $90^{\text {th }}$ percentile using the Abt and TFNC recommended consumption rate of maize respectively (Table 5). Exposure (PDI) to $\mathrm{AFB}_{1}$ ranged from 3.26 to $1,141.78 \mathrm{ng} / \mathrm{kg}$ bw/day, using consumption rates reported by Abt of $429.4 \mathrm{~g} /$ person/day, and from 5.86 to 2,050.10 $\mathrm{ng} / \mathrm{kg}$ bw/day, using consumption rate of $771 \mathrm{~g} /$ person/day recommended by TFNC (Table 4). Average exposure rates ranged from 3.94 to $315.48 \mathrm{ng} / \mathrm{kg}$ bw/day and from 7.07 to $566.46 \mathrm{ng} / \mathrm{kg}$ bw/day using the consumption rates reported by Abts and TFNC, respectively (Table 4).

Groundnut consumptions were different depending on the region under study; using the Abt Associates (2012) rates, for instance, exposure to total aflatoxin ranged from 0.02 to $15.12 \mathrm{ng} / \mathrm{kg}$ bw/day, with an average of $2.39 \mathrm{ng} / \mathrm{kg} \mathrm{bw} /$ day, and a $90^{\text {th }}$ percentile of $8.62 \mathrm{ng} / \mathrm{kg}$ bw/day (Table 6). The probable daily intake of $\mathrm{AFB}_{1}$ ranged between 0.10 and $14.37 \mathrm{ng} / \mathrm{kg}$ bw/day, with a mean of $1.88 \mathrm{ng} / \mathrm{kg} \mathrm{bw} /$ day and a $90^{\text {th }}$ percentile of $7.03 \mathrm{ng} / \mathrm{kg}$ bw/day (Table 2).

\section{Discussion}

Maize is the main dietary staple food for most Tanzanians and together with groundnuts, they are used as main ingredients for complementary foods. Unfortunately, these crops are susceptible to diverse opportunistic fungi and therefore, vulnerable to mycotoxin contamination (Suileman and Rosentrater, 2015). In the current study, all maize and groundnut samples from surveyed districts were contaminated with aflatoxin. The prevalence of aflatoxins was higher in groundnuts, where $96 \%$ of the samples had detectable aflatoxin levels, compared to $50 \%$ for maize. Similar results have previously been reported for Tanzania by different researchers (Kamala et al., 2015; Kimanya et al., 2014; Magembe et al., 2016; Manjula et al., 2009). A study conducted by Kimanya et al. (2008) found $18 \%$ of maize samples contaminated with aflatoxins, with levels of up to $158 \mu \mathrm{g} / \mathrm{kg}$, and $12 \%$ of the samples had $\mathrm{AFB}_{1}$ levels above the Tanzania maximum tolerable limit of $5 \mu \mathrm{g} / \mathrm{kg}$ (TBS, 2004). In another study, Magoha et al. (2014b) found that $57 \%$ of 67 maize flour samples contained detectable aflatoxins, that ranged from $0.33-69.47 \mu \mathrm{g} / \mathrm{kg}$. The high prevalence of aflatoxins in groundnut compared to maize has previously been reported (Magembe et al., 2016; Seetha et al., 2017). Thus, our results agree with those reported earlier for Tanzania, where aflatoxins were detected in all districts sampled, with other districts having higher incidences than others (TFDA, 2012). The current study included more districts in a single study (larger sample size) than in earlier reports. Compared to maize, groundnut was highly contaminated by aflatoxins, probably because the pods develop in the soil where $A$. flavus resides.

In Tanzania, the maximum tolerable limits for $\mathrm{AFB}_{1}$ and total aflatoxins are 5 and $10 \mu \mathrm{g} / \mathrm{kg}$, respectively (TBS, 2004). Contamination levels above these maximum tolerable limits were observed in some groundnut and maize samples. Our study provides additional information supporting earlier reports that Tanzanian maize and groundnuts are contaminated with unacceptable levels of aflatoxins (Kamala et al., 2015; Kimanya et al., 2008). High incidences of and levels of aflatoxin in maize and groundnut have also been reported in other countries in Africa (Lewis et al., 2005; Misihairabgwi et al., 2017). Two districts in central Tanzania, Kilosa and Ifakara, stood out as having high levels of aflatoxin in maize, confirming previous reports of higher aflatoxin levels in this region (Kamala et al., 2015; Magembe et al., 2016). This zone is prone to high incidences of drought, conditions that are conducive for A. flavus infection and aflatoxin contamination (Timiza, 2011). A study by Seetha et al. (2017) reported high levels of toxigenic $A$. flavus strains in central Tanzania, including Kilosa, and a ten-year (2007-2016) review of mycotoxin contamination of foods in Southern Africa by Misihairabgwi et al. (2017) shows a similar trend for the region.

It has been shown that health risks associated with mycotoxins can be reduced through awareness campaigns (Magembe et al., 2016; Seetha et al., 2017). However, results from this study revealed that more than $75 \%$ of the stakeholders were not aware of aflatoxins and associated health impacts from consumption of aflatoxincontaminated products. Similar observations have previously been made in Tanzania and it was shown that awareness of aflatoxin and health impacts varied between districts (Kimanya et al., 2014; Magembe et al., 2016; TFDA, 2012). Aflatoxin awareness levels were high in a few districts largely because of presence of projects dealing with aflatoxin or where traders had rejected commodities for export due to aflatoxins. This variation is probably a reflection of the different aflatoxin campaign efforts that have been going on across the country (Seetha et al., 2017). Lack of awareness of aflatoxins among stakeholders (farmers, traders, and consumers) and policy makers 
Table 6. Prevalence, consumption, concentration, probable daily intake (PDI), average probable daily intake (APDI) and maximum probable daily intake (MPDI) of total aflatoxins in groundnut consumed in different districts of Tanzania.

\begin{tabular}{|c|c|c|c|c|c|c|c|}
\hline District & $\begin{array}{l}\text { Concentration } \\
\text { range of positive } \\
\text { samples }(\mu \mathrm{g} / \mathrm{kg})\end{array}$ & $\begin{array}{l}\text { Mean } \\
\text { concentration } \\
(\mu \mathrm{g} / \mathrm{kg})\end{array}$ & $\begin{array}{l}90^{\text {th }} \text { percentile } \\
\text { concentration } \\
(\mu \mathrm{g} / \mathrm{kg})\end{array}$ & $\begin{array}{l}\text { Consumption } \\
\text { (g/person/day) }\end{array}$ & $\begin{array}{l}\text { PDI range } \\
\text { (ng/kg bw/day) }^{1}\end{array}$ & $\begin{array}{l}\text { APDI } \\
\text { (ng/kg } \\
\text { bw/day) }{ }^{1}\end{array}$ & $\begin{array}{l}\text { MPDI } \\
\text { (ng/kg } \\
\text { bw/day) }{ }^{1}\end{array}$ \\
\hline Babati & $1.42-40.31$ & $7.69 \pm 2.25$ & 22.845 & 3.20 & $0.0757-2.1499$ & 0.40997 & 1.21840 \\
\hline Bukombe & $0.90-30.07$ & $7.63 \pm 2.29$ & 26.010 & 29.70 & $0.4455-14.8847$ & 3.77477 & 12.87495 \\
\hline Chamwino & $0.08-23.6$ & $3.25 \pm 1.17$ & 7.285 & 36.40 & $0.0485-14.3173$ & 1.96924 & 4.41957 \\
\hline Iringa Rural & $0.51-36.09$ & $10.931 \pm 2.91$ & 30.780 & 14.10 & $0.1199-8.4812$ & 2.56868 & 7.23330 \\
\hline Kahama & $1.10-33.59$ & $6.100 \pm 1.95$ & 20.260 & 29.76 & $0.5456-16.6606$ & 3.02560 & 10.04896 \\
\hline Masasi & $0.08-37.54$ & $8.154 \pm 2.41$ & 23.080 & 15.10 & $0.0201-9.4476$ & 2.05206 & 5.80847 \\
\hline Nanyumbu & $0.06-32.44$ & $7.027 \pm 2.39$ & 29.030 & 15.10 & $0.0151-8.1641$ & 1.76855 & 7.30588 \\
\hline Nzega & $0.04-18.42$ & $4.627 \pm 1.38$ & 15.845 & 29.70 & $0.0198-9.1179$ & 2.29037 & 7.84328 \\
\hline Urambo & $0.34-14.74$ & $2.499 \pm 0.73$ & 4.840 & 29.70 & $0.1683-7.2963$ & 1.23698 & 2.39580 \\
\hline Average & $0.04-40.31$ & $6.373 \pm 0.68$ & 22.990 & 22.50 & $0.015-15.1163$ & 2.39005 & 8.62125 \\
\hline
\end{tabular}

${ }^{1}$ Groundnut consumption adopted from the report by Abt Associates (2014). Body weight (bw) is $60 \mathrm{~kg}$.

exacerbate the problem of mycotoxins in Tanzania. Regulation is unlikely to work as has been observed in other countries across Africa (Matumba et al., 2014), where most of the population eat what they produce. As a result, it is difficult to enforce laws. However, there is a growing peri urban and urban population that depends on food produced in rural areas, and as such, rising aflatoxin awareness may increase the demand for aflatoxin-safe food, which in turn might facilitate adoption of aflatoxin mitigating strategies and enforcement of regulations in rural areas. There is an urgent need to raise awareness among producers and consumers on the detrimental effects of aflatoxin exposure and available strategies to minimise contamination. These strategies include good agricultural practices (such as using improved seed, use of Aflasafe (biological control), use of fertilisers, good harvesting and handling procedures, storing properly dried grain and avoiding contact of grain with soil), use of improved storage structures, such as hermetic bags, and diversifying the diet to minimise consumption of crops highly prone to contamination with aflatoxin (Hell et al., 2005). Such campaigns should be streamlined according to gender and income of target populations.

$\mathrm{AFB}_{1}$ is considered the most potent form of aflatoxin (IARC, 2002). An economic assessment conducted by Abt Associates in collaboration with Tanzania Food and Drugs Authority (TFDA) observed significantly high prevalence of $\mathrm{AFB}_{1}$ in multiple regions around Tanzania (TFDA, 2012). In this study, $\mathrm{AFB}_{1}$ was detected in most samples collected and levels were higher in groundnut samples from Southern parts of the country and in maize collected from Northern and Eastern parts of the country. Two districts, Kilosa and Ifakara in central Tanzania had the highest levels of $\mathrm{AFB}_{1}$. Central and eastern Tanzania are generally drier and hotter than other regions in Tanzania. Infection and proliferation of A. flavus are favoured by high temperatures and humidity and drought conditions during crop growth (Holbrook et al., 2000; Richard, 2007). The weather conditions found in Kilosa and Ifakala are conducive for infection and proliferation of A. flavus and aflatoxin contamination.

Considering the maximum tolerable limits set by the EU of $4 \mu \mathrm{g} / \mathrm{kg}, 31 \%$ groundnut samples and $11.5 \%$ of maize samples were not suitable for human consumption. The risk of exposure to aflatoxin is high, especially for people subsisting on groundnuts and maize. Exposure to aflatoxin is a function of the level of contamination, the amount consumed and the frequency of consumption. In Tanzania, people consume an average of $429 \mathrm{~g}$ of maize per day (Ranún et al., 2014), and consumption rates as high as $771 \mathrm{~g} /$ day/person have been recommended (TFNC, 1997). Therefore, even the low levels of aflatoxins observed in this study are a potential health hazard, given the high rates of maize consumption in Tanzania. More than $80 \%$ of the population in Tanzania depends on maize as a food and cash crop (Moshi, 1997). Furthermore, groundnuts and maize are major components of weaning foods in Tanzania (Magoha et al., 2014b). High levels of aflatoxin have been reported in blood and urine of children up to 12 months from Morogoro district of Tanzania (Shirima et al., 2013). The levels of aflatoxin increased with age, and as children started taking weaning foods. The risk of aflatoxin exposure in children receiving complementary weaning foods is very high in Tanzania (Shirima et al., 2013). 
Apart from being associated with some chronic health risks, such as cancer and immune suppression, aflatoxin is also associated with child stunting (Gong et al., 2016; Leroy, 2013). In sub-Saharan Africa and South Asia, prevalent stunting in children under five years old has been reported (Black et al., 2013) with insignificant reduction overtime through nutrition-specific interventions, such as micronutrient supplementation and fortification, as well as complementary feeding (Lutter et al., 2011). This situation, however, has been linked to aflatoxin contamination of weaning foods supplied to the children (Gong et al., 2016). The central region of Tanzania has one of the highest stunting levels in the country, with Dodoma district reporting over $40 \%$ stunting in children under the age of 5 years (TFNC, 2014). A recent study conducted in Iringa, Tabora, and the Kilimanjaro regions of Tanzania, showed that $67 \%$ of children had serum aflatoxin biomarkers with a mean aflatoxin-albumin adduct concentration of $4.7 \mathrm{pg} / \mathrm{mg}$ of albumin (Shirima et al., 2013). Therefore, results from this study reveal a chronic problem of exposure to aflatoxins, coming from both groundnuts and maize consumption. This study revealed high levels of aflatoxins in Kilosa and Ifakara districts, and these two districts have been traditionally associated with high levels of child stunting (Shirima et al., 2013).

Within the East Africa region, Tanzania has the highest maize and groundnuts consumption, at $429 \mathrm{~g} /$ person/ day and $15 \mathrm{~g} /$ person/day, respectively (Abt Associates, 2012; Ranún et al., 2014). Average national consumption is estimated to be over three million metric tons per year (FAOSTAT, 2014). Maize is a major staple produced mostly by smallholder farmers (71\%) for own consumption (Suleiman and Rosentrater, 2015). Thus, even low levels of contamination is a potential health risk, especially for people consuming large amounts of maize, as in Tanzania. Estimated average probable daily intake of $\mathrm{AFB}_{1}$ from groundnut consumption was $1.88 \mathrm{ng} / \mathrm{kg}$ bw/day with a maximum of $14.37 \mathrm{ng} / \mathrm{kg}$ bw/day. For maize, the average intake ranged from 151.98 to $272.89 \mathrm{ng} / \mathrm{kg}$ bw/day. These levels exceeded the provisional maximum tolerable daily intake (PMTDI) of $1 \mathrm{ng} \mathrm{AFB}_{1} / \mathrm{kg}$ bw/day for adults for adults without hepatitis $\mathrm{B}$, and $0.4 \mathrm{ng} \mathrm{AFB}_{1} / \mathrm{kg} \mathrm{BW} /$ day for adults with hepatitis B quoted by Kuiper-Goodman (1998), revealing that the Tanzanian population is at high risk of $\mathrm{AFB}_{1}$ exposure. Given that both maize and groundnut are major components of complementary and weaning foods in Tanzania, the exposure levels are worrisome, as they exceeded the health concern level of $0.017 \mathrm{ng} / \mathrm{kg} \mathrm{BW} /$ day recommended by the European Food Safety Agency (EFSA) for food to be consumed by infants (Barlow et al., 2006; EFSA, 2007). High risk of exposure from consumption of maize has been reported for Tanzania (Kamala et al., 2018; Kimanya et al., 2014; Magembe et al. 2016; Magoha et al., 2014b). A study by Kimanya et al. (2014) reported that in Rombo District, North Eastern Tanzania, the risk of exposure for children consuming maize flour ranged from 1 to $786 \mathrm{ng} / \mathrm{kg} \mathrm{bw} /$ day. Therefore, measures need to be put in place to educate the population on the health impacts of aflatoxins, as well as provide solutions to prevent aflatoxin contamination of maize and groundnuts (Nathaniels, 2014).

\section{Conclusions and recommendations}

This study revealed widespread contamination of maize and groundnuts with aflatoxin in Tanzania. Smallholder farmers, who consume what they grow, are at the highest risk of aflatoxin exposure, especially for maize because of the higher levels of contamination and secondly because the average person eats more maize per day than other foods. Aflatoxin awareness is generally low; extra efforts are required to raise aflatoxin awareness among stakeholders along the maize and groundnut value chains. More studies are required to better map the distribution and prevalence of aflatoxins, focusing on other regions that were not part of this study and in multiple seasons. This will allow mapping variations in aflatoxin contamination and levels relative to prevailing environmental conditions. In addition, sampling in multiple years will provide the required information to develop more accurate aflatoxin risk maps and better target intervention strategies. Strategies to minimise impact of aflatoxins on human health should involve educating farmers, producers, processors and consumers about aflatoxins, health impacts and strategies for minimising contamination.

\section{Supplementary material}

Supplementary material can be found online at https://doi. org/10.3920/WMJ2020.2646.

Figure S1. A map of Tanzania showing the geographical locations from where maize and groundnut samples were collected in 2012 to conduct a mycotoxin prevalence study.

\section{Conflict of interest}

The authors declare that there are no conflicts of interest.

\section{Acknowledgements}

The authors would like to thank TFDA for aflatoxin analysis, SUA, TPRI and MA in Tanzania for attending the stakeholders' inception workshop and helping with the survey and sample collection; IITA as a host and all other participants in the stakeholders' inception workshop including Civil Education is the Solution for Poverty and Environmental Management (CESOPE) - all Tanzanian and Ohio State University - international institutions. This study was jointly funded by the USAID's Feed the Future Africa Rising initiative and the Bill \& Melinda Gates Foundation (OPP1007117) as part of the CGIAR Research Program on Agriculture for Nutrition and Health (A4NH). 


\section{References}

Abt Associates, 2012. Literature review to inform the aflatoxin country assessments: Tanzania and Nigeria. Abt Associates Inc., Bethesda, MD, USA. Available at: https://tinyurl.com/ybhhe7tl

Abt Associates, 2014. Country and economic assessment for aflatoxin contamination and control in Tanzania. Preliminary findings. Abt Associates Inc., Bethesda, MD, USA. Available at: https://tinyurl. com/y3pgoq42

Barlow, S., Renwick, A.G., Kleiner, J., Bridges, J.W., Busk, L., Dybing, E., Edler, L., Eisenbrand, G., Fink-Gremmels, J., Knaap, A., Kroes, R., Liem, D., Müller, D.J., Page, S., Rolland, V., Schlatter, J., Tritscher, A., Tueting, W. and Würtzen, G., 2006. Risk assessment of substances that are both genotoxic and carcinogenic. Report of an International Conference organized by EFSA and WHO with support of ILSI Europe. Food and Chemical Toxicology 44: 1636-1650.

Black, R.E., Victora, C.G., Walker, S.P., Bhutta, Z.A., Christian, P., De Onis, M., Ezzati, M., Grantham-McGregor, S., Katz, J., Martorell, R. and Uauy, R., 2013. Maternal and child undernutrition and overweight in low-income and middle-income countries. Lancet 382: 427-451.

East African Community (EAC), 2011. East African standards: maize grains - specification. EAC, Dar es Salaam, Tanzania. Available at: https://law.resource.org/pub/eac/ibr/eas.2.2011.html

Essono, G., Ayodele, M., Akoa, A., Foko, J., Olembo, S. and Gockowski, J., 2007. Aspergillus species on cassava chips in storage in rural areas of southern Cameroon: their relationship with storage duration, moisture content and processing methods. African Journal of Microbiology Research 1: 1-8.

European Commission (EC), 2010. Guidance document for competent authorities for the control of compliance with EU legislation on aflatoxins. Regulation No 1152/2009. EC, Brussels, Belgium. Available at: http://ec.europa.eu/food/food/chemicalsafety/ contaminants/guidance-2010.pdf

European Food Safety Authorisation (EFSA), 2007. Opinion of the Scientific Panel on Contaminants in the Food Chain on a request from the Commission related to the potential increase of consumer health risk by a possible increase of the existing maximum levels for aflatoxins in almonds, hazelnuts and pistachios and derived products. EFSA Journal 2007: 446.

Food and Agriculture Organization of the United Nations (FAO), 2004. Worldwide regulations for mycotoxins in food and feed. FAO Food and Nutrition Paper 81: 1-30.

Food and Agriculture Organization of the United Nations, Statistics Division (FAOSTAT), 2014. Crops. FAO, Rome, Italy. Available at: http://www.fao.org/faostat/en/\#data/QC

Gong, Y.Y., Watson, S. and Routledge, M.N., 2016. Aflatoxin exposure and associated human health effects, a review of epidemiological studies. Food Safety 4: 14-27.

Hell, K., Fandohan, P., Bandyopadhyay, R., Kiewnick, S., Sikora, R. and Cotty, P.J., 2005. Pre and post-harvest management of aflatoxin in maize: an African perspective. In: Leslie, J.F., Bandyopadhyay, R. and Visconti, A. (eds.) Mycotoxins: detection methods, management, public health and agricultural trade. Cromwell Press, Trowbridge, UK, pp. 219-229.
Herrman, J.L. and Yunes, M., 1999. Background to the ADI/TDI/ PTWI. Regulatory Toxicology and Pharmacology 30: S109-S113.

Holbrook, C.C., Kvien, C.K., Rucker, K.S., Wilson, D.M., Hook, J.E. and Matheron, M.E., 2000. Preharvest aflatoxin contamination in drought-tolerant and drought-intolerant peanut genotypes 1 . Peanut Science 27: 45-48.

International Agency for Research on Cancer (IARC), 2002. Aflatoxins. In: Monograph on the evaluation of carcinogenic risks to humans. Vol. 82. Some traditional herbal medicines, some mycotoxins, naphthalene and styrene. IARC, Lyon, France, pp. 171-300.

Kamala, A., Ortiz, J., Kimanya, M., Haesaert, G., Donoso, S., Tiisekwa, B. and De Meulenaer, B., 2015. Multiple mycotoxin co-occurrence in maize grown in three agro-ecological zones of Tanzania. Food Control 54: 208-215.

Kamala, A., Shirima, C., Jani, B., Bakari, M., Sillo, H., Rusibamayila, N., De Saeger, S., Kimanya, M., Gong, Y.Y. and Simba, A., 2018. Outbreak of acute aflatoxicosis in Tanzania during 2016. World Mycotoxin Journal 11: 311-320.

Kimanya, M.E., De Meulenaer, B., Tiisekwa, B., Ndomondo-Sigonda, M, Devlieghere, F. and Kolsteren, P., 2008. Co-occurrence of fumonisins with aflatoxins in home stored maize for human consumption in rural villages of Tanzania. Food Additives and Contaminants Part A 25: 1353-1364.

Kimanya, M.E., Shirima, C., Magoha, H., Shewiyo, D.H., De Meulenaer, B., Kolsteren, P. and Gong, Y.Y., 2014. Co-exposures of aflatoxins with deoxynivalenol and fumonisins from maize based complementary foods in Rombo, Northern Tanzania. Food Control 41: 76-81.

Kuiper-Goodman, T., 1998. Food safety: mycotoxins and phycotoxins in perspective. In: Miraglia, M., Van Egmond, H., Brera, C. and Gilbert J. (eds.) Mycotoxins and phycotoxins - developments in chemistry, toxicology and food safety. International Union of Pure and Applied Chemistry (IUPAC), Oxford, UK.

Leroy, J.F., 2013. Aflatoxins: finding solutions for improved food safety, child stunting and aflatoxins. Research program on agriculture for nutrition and health, 2020 vision. International Food Policy Research Institute, Washington, DC, USA.

Lewis, L., Onsongo, M., Njapau, H., Schurz-Rogers, H., Luber, G., Kieszak, S., Nyamongo, J., Backer, L., Dahiye, A.M., Misore, A., DeCock, K. and Rubin, C., 2005. Aflatoxin contamination of commercial maize products during an outbreak during an outbreak of acute aflatoxicosis in Eastern and Central Kenya. Environmental Health Perspectives 113: 1763-1767.

Lombard, M.J., 2014. Mycotoxin exposure and infant and young child growth in Africa: what do we know? Annals of Nutrition and Metabolism 64: 42-52.

Lutter, C.K., Daelmans, B.M., De Onis, M., Kothari, M.T., Ruel, M.T., Arimond, M., Deitchler, M., Dewey, K.G., Blössner, M. and Borghi, E., 2011. Undernutrition, poor feeding practices, and low coverage of key nutrition interventions. Pediatrics 128: 1418-1427.

Magembe, K.S., Mwatawala, M.W., Mamiro D.P. and Chingonikaya, E.E., 2016. Assessment of awareness of mycotoxins infections in stored maize (Zea mays L.) and groundnut (Arachis hypogea L.) in Kilosa District, Tanzania. International Journal of Food Contamination 3: 12. https://doi.org/10.1186/s40550-016-0035-5 
Magoha, H., Kimanya, M., De Meulenaer, B., Roderfroid, D., Lachat, C. and Kolsteren, P., 2014a. Association between aflatoxin $M_{1}$ exposure through breast milk and growth impairment in infants from Northern Tanzania. World Mycotoxin Journal 7: 277-284.

Magoha, H., Kimanya, M., De Meulenaer, B., Roderfroid, D., Lachat, C. and Kolsteren, P., 2014b. Risk of dietary exposure to aflatoxins and fumonisins in infants less than 6 months of age in Rombo, Northern Tanzania. Maternal and Child Nutrition 12: 516-527.

Manjula, K., Hell, K., Fandohan, P., Abass, A. and Bandyopadhyay, R., 2009. Aflatoxin and fumonisin contamination of cassava products and maize grain from markets in Tanzania and Republic of the Congo. Toxin Reviews 28: 63-69.

Matumba, L., Van Poucke, C., Njumbe Ediage, E. and De Saeger, S., 2014. Keeping mycotoxins away from the food: does the existence of regulations have any impact in Africa? Critical Reviews in Food Science and Nutrition 57: 1584-1592.

Milani, J.M., 2013. Ecological conditions affecting mycotoxin production in cereals: a review. Veterinari Medicina 58: 405-411.

Misihairabgwi, J.M., Ezekiel, C.N., Sulyok, M., Shephard, G.S. and Krska, R., 2017. Mycotoxin contamination of foods in Southern Africa: a 10-year review (2007-2016). Critical Reviews in Food Science and Nutrition 11: 1-16. https://doi.org/10.1080/1040839 8.2017.1357003

Moshi, A., 1997. Economic impact of maize research in Tanzania. Southern African Center for Cooperation in Agricultural and Natural Resources Research and Training, Gaborone, Botswana.

Nathaniels, N.Q., 2014. Communicating aflatoxin messages: recent Tanzanian experience. International Institute of Tropical Agriculture. Available at: https://tinyurl.com/y3nocxzk

Ranún, P., Peña-Rosas, J.B. and García-Casal, M.N., 2014. Global maize production, utilization, and consumption. Annals of the New York Academy of Sciences 1312: 105-112.

Richard, J.L., 2007. Some major mycotoxins and their mycotoxicoses an overview. International Journal of Food Microbiology 119: 3-10.

Samapundo, S., De Meulenaer, B., Oseri-Nimoh, D., Lamboni, Y., Debevere, J. and Devlieghere, F., 2007. Can phenolic compounds be used for the protection of corn from fungal invasion and mycotoxin contamination during storage? Food Microbiology 24: 465-473.

Schroeder, H.W., 1969. Factors influencing the development of aflatoxins in some field crops. Journal of Stored Products Research 5: $187-190$.

Seetha, A., Munthali, W., Msere, H.W., Swai, E., Muzanila, Y., Sichone, E., Tsusaka, T.W., Rathore, A. and Okori, P., 2017. Occurrence of aflatoxins and its management in diverse cropping systems of central Tanzania. Mycotoxin Research 33: 323-331.

Shephard, G.S., 2008. Risk assessment of aflatoxins in food in Africa. Food Additives and Contaminants Part A 25: 1246-1256.
Shirima, C.P., Kimanya, M.E., Kinabo, J.L., Routledge, M.N., Srey, C., Wild, C.P. and Gong, Y.Y., 2013. Dietary exposure to aflatoxin and fumonisin among Tanzanian children as determined using biomarkers of exposure. Molecular Nutrition and Food Research 57: 1874-1881.

Stroka, J., Anklam, E., Jorissen, U. and Gilbert, J., 2000. Immunoaffinity column cleanup with liquid chromatography using post-column bromination for determination of aflatoxins in peanut butter, pistachio paste, fig paste, and paprika powder: collaborative study. Journal of AOAC International 83: 320-340.

Suleiman, R.A. and Rosentrater, K.A., 2015. Current maize production, postharvest losses and the risk of mycotoxins contamination in Tanzania. Agricultural and Biosystems Engineering Conference Proceedings and Presentations 442. Available at: https://lib.dr.iastate. edu/abe_eng_conf/442

Tanzania Bureau of Standards (TBS), 2004. Rice specification. TZS 592. TBS. Dar es Salaam, Tanzania.

Tanzania Food and Drugs Authority (TFDA), 2012. Aflatoxin contamination and potential solutions for its control in Tanzania. A summary of the country and economic assessment conducted in 2012 and the aflatoxin stakeholder workshop. December 3-4, 2012. Dar es Salaam, Tanzania.

Tanzania Food and Nutriction Center (TFNC), 1997. Matumizi ya kadi ya uhakika wa chakula katika kaya. Mwongozo kwa wafanyakazi wa ugani. TFNC, Dar es Salaam, Tanzania, 14 pp.

Tanzania Food and Nutrition Center (TFNC), 2014. Tanzania National Nutrition Survey, 2014, final report. The United Republic of Tanzania Ministry of Health and Social Welfare, Dar es Salaam, Tanzania.

Timiza, W., 2011. Climate variability and satellite-observed vegetation responses in Tanzania. MSC-thesis, Physical Geography and Ecosystem Analysis, Lund University, Lund, Sweden.

US Food and Drug Administration (USFDA), 2015. Guidelines for aflatoxin levels. USFDA, Silver Spring, MD, USA. Available at: http://agriculture.mo.gov/plants/feed/aflatoxin.php

Visconti, A. and Perrone, G., 2008. The EU MycoGlobe project: global integration of mycotoxin and toxigenic fungal research for enhanced food safety. In: Leslie, J.F., Bandyopadhyay, R. and Visconti, A. (eds.) Mycotoxins: detection methods, management, public health and agricultural trade. CAB International, Cromwell Press, Trowbridge, UK, pp. 3-9.

World Health Organization (WHO), 2018. Aflatoxins. Department of Food Safety and Zoonoses. Ref. No.: WHO/NHM/FOS/RAM/18.1. WHO, Geneva, Switzerland. Available at: http://www.who.int/ foodsafety/Food_Safety_Digest_Aflatoxins_EN.pdf

Wu, F., 2004. Mycotoxin risk assessment for the purpose of setting international regulatory standards. Environmental Science and Technology 38: 4049-4055. 